1987

\title{
Feminism and Legal Method: The Difference it Makes
}

Mary Jane Mossman

Osgoode Hall Law School of York University, mjmossman@osgoode.yorku.ca

Source Publication:

Wisconsin Women's Law Journal (now Wisconsin Journal of Law, Gender and Society). Volume 3 (1987), p. 147-168.

Follow this and additional works at: https://digitalcommons.osgoode.yorku.ca/scholarly_works

Part of the Civil Rights and Discrimination Commons, Law and Gender Commons, and the Legal Profession Commons

(c) $($ ) $\Theta \Theta$

This work is licensed under a Creative Commons Attribution-Noncommercial-No Derivative Works 4.0 License.

\section{Recommended Citation}

Mossman, Mary Jane. "Feminism and Legal Method: The Difference it Makes." Wisconsin Women's Law Journal 3 (1987): 147-168.

This Article is brought to you for free and open access by the Faculty Scholarship at Osgoode Digital Commons. It has been accepted for inclusion in Articles \& Book Chapters by an authorized administrator of Osgoode Digital Commons. 


\title{
FEMINISM AND LEGAL METHOD: THE DIFFERENGE IT MAKES*
}

\author{
Mary Jane Mossman,**
}

\begin{abstract}
Introduction
The fact that our understanding of Homo Sapiens has incorporated the perspective of only half of the human race makes it clear that women's studies is not an additional knowledge merely to be tacked on to the curriculum. It is, instead, a body of knowledge that is perspective transforming and should therefore transform the existing curriculum from within and revise received notions of what constitutes an "objective" or "normative" perspective (emphasis in original). ${ }^{1}$
\end{abstract}

These words appeared in A Feminist Perspective in the Academy: The Difference It Makes, a book of essays about the impact of feminist ideas on a number of academic disciplines, including literature, drama, economics, sociology, history, political science, anthropology, psychology, and religious studies. The authors of these essays suggested that a feminist perspective has only just begun to "affect the shape of what is known-and knowable - in their respective disciplines."2

The authors also asserted that a feminist perspective "challenges deeply held, often sacred beliefs, beliefs that are rooted in emotions and expressed in primitive imagery." As well, it "challenges vested interests, [and] uproots perspectives which are familiar, and, because familiar, comfortable." In short, "feminist ideas are a challenge to the status quo."3

Given these perceptions about the transforming impact of feminism

* Reprinted with permission from the Australian Journal of Law and Society.

** Associate Professor, Osgoode Hall Law School.

*** An early version of this paper was originally presented to the Feminist Legal Issues Conference at Marquarie University in Sydney, Australia in March 1986. At that time, I paid tribute to some of my former students at the University of New South Wales, including Margaret Thornton, Pat O'Shane and the late Helen Goulding, who asked questions when $I$ began to teach there in 1972 that have continued to energize my thinking ever since. I acknowledge their inspiration and that of my students over many years at Osgoode most gratefully.

I am also appreciative of the helpful comments and generous support of the participants in the Feminism and Legal Theory Conference-Women and Differences at the University of Wisconsin-Madison in July 1986; and the warm encouragement of my good friend Beverly Baines in the continuing process of writing this paper.

1. E. Langland and W. Gove, eds. A Feminist Perspective in the Academy: The Difference It Makes (1981) at 3.

2. Id. at 2.

3. Id. at 2-3. 
on the world of ideas, why did this collection not include an essay about the impact of feminist ideas on law ? ${ }^{4}$ Moreover, what seems at first glance a mere oversight becomes on closer inspection a question of great significance: to what extent can feminist theory impact, if at all, on the structure of legal inquiry? In the law's process of determining facts, choosing and applying principles, and reaching reasoned decisions, is there any scope for feminism's fundamental challenge to our "ways of knowing"?

This question needs to be addressed in the context of the definition of feminism adopted by the editors of $A$ Feminist Perspective in the Academy:

... [A]ll feminists . . . would agree that women are not automatically or necessarily inferior to men, that role models for females and males in the current Western societies are inadequate, that equal rights for women are necessary, that it is unclear what by nature either men or women are, that it is a matter for empirical investigation to ascertain what differences follow from the obvious physiological ones, that in these empirical investigations the hypotheses one employs are themselves open to question, revision, or replacement. ${ }^{6}$

The first part of this definition, especially the assertion that "equal rights for women are necessary," assumes the existence of inequality and the need for societal change. In this respect, the definition represents a clear challenge to the status quo.

Yet, the latter part of the definition represents an even more fundamental challenge: feminism's quest for an understanding of the nature of men and women demands a reassessment of the structure of our inquiry. Not only are the answers subject to scrutiny, but also the way in which we search for them. In challenging the validity of "facts," the possibility of "neutrality" and the equity of the "conclusions" which result from such analysis, the feminist perspective directs its attention to our "ways of

4. A similar collection of Dale Spender, ed., Men's Studies Modified: The Impact of Feminism on the Academic Disciplines (1981) does include an analysis of feminism in the context of law as an academic discipline. See O'Donovan, Before and After: The Impact of Feminism on the Academic Discipline of Law in Spender, supra, at 175. The ideas expressed in O'Donovan's essay and in her book, Sexual Divisions in Law (1985) stimulated my interest in this subject.

5. The phrase is similar to that used by O'Donovan in Sexual Divisions in Law, supra n.4, at 59, where she refers to a "way of seeing":

When a particular way of seeing is analysed, what was accepted as natural is made strange. Part of that strangeness is the realisation that beneath the accepted order of life lie hidden power relations.

Both phrases focus on the method of understanding ideas, but "ways of knowing" is more explicit about the cognitive process itself. See also Finn, On the Oppression of Women in Philosophy-Or, Whatever Happened to Objectivity? in Miles and Finn, Feminism in Canada: From Pressure to Politics (1982) at 145.

6. Barnes, Female Criticism: A Prologue in A. Diamond and L. Edwards, eds., The Authority of Experience: Essays in Feminist Criticism (1977); as quoted in E. Langland and W. Gove, eds., supra n.1, at 3. 
knowing" about men and women as well as to our efforts to seek greater equality for women. Such a quest, moreover, may require new methods of inquiry:

.. . Traditional methods are inadequate for women who wish to understand and change their circumstances. . . . Women, after all, have been studied as objects for centuries, just as slaves, barbarians and workers have been studied. What happens, however, when women, slaves, barbarians or workers wish to become actors in the discovery process while they remain an oppressed (or at least powerless) group, caste or class? Since there is a high convergence between those who hold power over them and those who make the tools of thinking which 'explain' and 'justify' reality, they will learn little of themselves useful for achieving change by employing the intellectual tools of their oppressors.

Can such a feminist agenda be accommodated within the legal system? Traditionally, legal method has operated within a highly structured framework which offers little opportunity for fundamental questioning about the process of defining the issues, selecting relevant principles, and excluding irrelevant ideas. In this context, decision-making takes place according to a form which usually "sees" present questions according to patterns established in the past, and in a context in which ongoing consistency in ideas may be valued more often than their future vitality.

To explore this relationship between feminism and legal method, I decided to try to identify the features of legal method in practice, and to do so in the context of "women's rights" cases, in which the claims being asserted might be expected to reflect feminist ideas and objectives. This paper is a case study of two early 20th century cases which illustrate quite well the approaches used by judges in deciding claims concerning new roles for women in society. With the benefit of our historical perspective, it is evident to us that the structure of the legal inquiry significantly affected the decisions in these two cases. This conclusion, moreover, provides the basis for beginning to assess the potential impact of feminism's "transforming perspective" in present day challenges to achieve sex equality.

\section{Women, Difference and Legal Method}

A few years before the nineteenth century drew to a close, Clara Brett Martin was admitted to the practice of law in Ontario; she was the first woman to become a lawyer in the British Commonwealth. ${ }^{8}$ Her petition for admission was initially denied by the Law Society because there were no precedents for admitting women to the practice of law. However,

7. McCalla-Vickers, Memoirs of an Ontological Exile: The Methodological Rebellions of Feminist Research; in Miles and Finn, eds., supra n.5, at 32.

8. Martin was admitted to practice in 1897 as a barrister and solicitor. For an excellent account of her efforts to become a lawyer, see Backhouse, 'To Open the Way for Others of my Sex'; Clara Brett Martin's Career as Canada's First Woman Lawyer, 1 Can. Journal of Women and the Law 1 (1985). 
in 1892 a legislative amendment was passed permitting women to practice as solicitors; three years later, another legislative amendment similarly permitted women to practice as barristers. ${ }^{\circ}$ In February 1897, Clara Brett Martin herself was admitted as a barrister and solicitor. ${ }^{10}$

Because of admission arrangements in Ontario, the Law Society of Upper Canada, rather than the superior court, reviewed Clara Brett Martin's entitlement to admission as a lawyer. ${ }^{21}$ By contrast, a court in the Province of New Brunswick reviewed Mabel French's ${ }^{12}$ admission to legal practice in 1905. When her application was presented to the court, the judges denied it unanimously, stating there were no precedents for the admission of women as lawyers. In the next year, however, after the enactment of a legislative amendment, Mabel French was admitted to legal practice in New Brunswick. ${ }^{13}$ The same pattern (judicial denial of the application followed by legislative amendment) occurred again some years later when she applied for admission by transfer to the legal profession in British Columbia, ${ }^{14}$ and in a number of the other Canadian provinces when women applied to be admitted to practice as lawyers. ${ }^{15}$.

9. The amendment to the Law Society Act which permitted Martin's entry to the legal profession was originally drafted in gender-specific language: "the admission of women." It was only in 1970 that the Act was amended so as to refer to "the admission of persons." See 55 V. ch. 32, s. 1 (1892) re: admission of women as solicitors; 58 V. ch. 27, s.1 (1985) re: admission as barristers-at-law; and S.O. 1970, ch. 19 for the admission of persons. The original provisions permitted the Law Society to exercise discretion in relation to admission, but this power was removed by Law Society Act, 1927, 2 Geo. v. ch. 26, s. 43.

10. Backhouse, supra n.8, at 31 .

11. For details of the arrangements and the conclusions of the Law Society of Upper Canada, see Backhouse, supra n.8, at 7-9.

12. In re French 37 N.B.R. 359 (1905).

13. $6 \mathrm{Ed}$. VII ch. 5 (1906). Some of the story of French's attempts to gain admission appears in A. Watts, Q.G., History of the Legal Profession in British Columbia 18691984 (1984) at 133-135. He states that French was admitted in New Brunswick on April 21, 1906. Id., at 133.

14. The Benchers in B.C. decided that ". . . they had no power . . . to admit ladies to the practice of law;" on an application for mandamus to the British Columbia Court of Appeal, the application was refused. See, In re French, 1 D.L.R. 80. [1912] According to Watts, supra n. 13, "the Law Society rather ungallantly, and contrary to what had happened to (sic) New Brunswick, [collected] its costs" in the case. In February 1912, after concerted efforts on the part of a number of women activists, legislation was passed permitting women to become lawyers. Mabel French was admitted on April 1, 1912. According to Watts, supra n. 13. Benchers' minutes of that date record the call of twenty gentlemen, including Ms. French! Mabel French thus has the distinction of becoming the first woman to be admitted to practice as a lawyer in both New Brunswick and British Columbia. She practiced law in British Columbia for a number of years, then married in 1923 and settled in Seattle. Her name has been perpetuated since 1966 in the Mabel Penury French Golf Cup, competed for by ladies in the annual meeting of the Law Society. See Watts, supra n.13, at 135.

15. See, for example, Langstaff v. Bar of Quebec, 25 Que. K.B. 11. (1915). A full list of the women first admitted for each province in Canada is found in Harvey, Women in Law in Canada, 4 Man. L. J. 9 (1970-71). 
In contrast to cases in which women sought to enter the legal profession and were denied admission by the courts, the Persons case ${ }^{16}$ provided that Canadian women were eligible to participate in public life. In the Persons case, five women ${ }^{17}$ challenged the meaning of the word "persons" in sections 24 of the British North America Act. Section 24 provided that the Governor General "shall . . . summon qualified Persons to the Senate"; there was no express requirement that Senators be male persons. Even though the language of the section was gender-neutral, no woman in Ganada had ever been summoned to become a senator.

In a constitutional reference to the Supreme Court of Ganada in $1928,{ }^{18}$ the judges concluded that women were not "persons" and therefore were not eligible to become Senators. ${ }^{19}$ On appeal to the Privy Council the next year, ${ }^{20}$ the decision was reversed. Ironically, it was in the Privy Council, and not in the indigenous courts of Canada, that the claim of "equal rights of women" to participate in public life was successful.

The decisions in these cases offer an interesting historical picture of legal process in the cultural milieu of the early twentieth century. In the cases about the admission of women to the legal profession, judges accepted the idea that there was a difference between men and women, a difference which "explained" and "justified" the exclusion of women from the legal profession. However, the Privy Council's decision in the Persons case completely discounted any such difference in relation to the participation of women in public life.

Why were there differing approaches to these claims: was it the nature of the claims, the type of court in which the claims were presented, or the time and context of the decisions? More significantly, what can we learn from the reasoning in these cases about the nature of legal method, especially in the context of challenges to deeply-held beliefs, vested interests, and the status quo? In other words, what do these cases suggest about the potential impact of feminism on legal method?

\section{The Idea of Difference}

Mabel French's case in New Brunswick provides a good illustration of judicial decision-making regarding women in law. Her case was

16. Reference re Meaning of the Word "Persons" in S. 24 of the B.N.A. Act, S.C.R. 276 [1928]; Edwards v. A.G. for Ganada, A.C. 124 [1930].

17. A petition was submitted by Henrietta Muir Edwards, Nellie L. McGlung, Louise C. McKinney, Emily F. Murphy and Irene Parlby; as a result, a reference was submitted to the Supreme Court of Canada by the Minister of Justice for a determination of the question.

18. There is some evidence that the government of the day recognized the potential controversy of the matter, and that a conscious decision was made to refer it to the court to avoid having to deal with the issue in the political arena. See D. Williams, Duff: A Life in the Law (1984), at 142-148; and J. Snell and F. Vaughan, The Supreme Court of Canada: History of the Institution (1985), at 141-143.

19. Supra n.16.

20. Supra n.16. 
presented to the court for direction as to the admissibility of women as lawyers by the president of the Barristers' Society of New Brunswick (as amicus curiae). The court decided that women were not eligible for admission to legal practice. The argument proceeded on a number of different levels. For example, Mr. Justice Tuck was concerned about the longterm implications of a decision allowing women to become lawyers. In the course of argument, he directed a comment to French's counsel:

If this young lady is entitled to be admitted an attorney she will in a year be entitled to be called to the bar, and, in a few years, will be eligible to be appointed to the bench. ${ }^{21}$

Responding, counsel suggested that such a development was not a "necessary sequence," but "if that be the inevitable consequence, worse things might happen. ${ }^{322}$ Perhaps it was this interchange which prompted Mr. Justice Tuck to explain in his decision:

If I dare to express my own views I would say that I have no sympathy with the opinion that women should in all branches of life come in competition with men. Better let them attend to their own legitimate business. ${ }^{23}$

Mr. Justice Tuck did not expand on his views as to the nature of women's "legitimate business." However, it seems likely that he would have agreed with the views expressed by Mr. Justice Barker in the case. Relying on the decision of the United States Supreme Court in Bradwell v. Illinois in 1873, ${ }^{24} \mathrm{Mr}$. Justice Barker adopted as his own the "separate spheres" doctrine enunciated there:

... The civil law, as well as nature herself, has always recognized a wide difference in the respective spheres and destinies of man and woman. Man is, or should be, woman's protector and defender. The natural and proper timidity and delicacy which belongs to the female sex evidently unfits it for many of the occupations of civil life. The constitution of the family organization, which is founded in the divine ordinance as well as in the nature of things, indicates the domestic sphere as that which properly belongs to the domain and functions of womanhood. ${ }^{25}$

The language of the Bradwell decision expressed very clearly an unqualified acceptance of the idea of difference between men and women, a difference which was social as well as biological. It is significant, however, that no evidence was offered for the assertions about the "timidity and delicacy" of women in general; no authorities were cited for the existence of "divine law" as articulated by Mr. Justice Barker; and no studies were examined in support of the conclusion that the domestic sphere belonged

21. Supra n.12, at 361 .

22. Id.

23. Id. at 361-62.

24. 16 Wall 130 (1872).

25. Supra n.12, at 365. 
"properly" to women (and vice versa). The court merely cited the existence of divine and natural law in general terms.

The legal reasoning used by Mr. Justice Barker does not seem consistent with the recognized principles of legal method: the reliance on relevant and persuasive evidence to determine facts, the use of legal precedents to provide a framework for analysis, and a rational conclusion supported by both evidence and legal principles. Yet, if $\mathrm{Mr}$. Justice Barker's ideas are not the product of legal method, what is their source?

The answer, of course, seems to be that the ideas he expressed were those prevailing in the cultural and professional milieu in which he lived. The ideas of mainstream religion, for example, emphasized the differences between men and women. ${ }^{26}$ Moreover, even when women and men were regarded as equal in the eyes of God (in the ideas of reformers such as Calvin, for example), women were still treated as subordinate to men, their subordination reflecting:

... the divinely created social order by which God has ordained the rule of some and the subjugation of others: rulers over subjects, masters over servants, husbands over wives, parents over children. ${ }^{27}$

The idea of a divinely-created "social office" in the religious tradition, which required women and men to perform quite different social roles, was reinforced by secular ideas in philosophy in which the role of the family defined women's roles. ${ }^{28}$ In much of the philosophical writing, women were defined "by their sexual, procreative, and child-rearing functions" within the family, and then the "constricted role in which [the woman was placed was] regarded as dictated by her very nature". ${ }^{29}$ Even John Stuart Mill, who was well-known for his progressive views about the rights of women, considered that equal rights to education, political life, and the professions could be granted only to single women who did not have family responsibilities. ${ }^{30}$

Moreover, even if Mr. Justice Barker had utilized scientific thought at the turn of the century, he would likely have found that the views expressed in religion and philosophy confirmed his own. Because the scientific inquiry took place in an already-existing framework of knowledge, it was almost inevitable that scientists would "find" the answers to ques-

26. See R. Radford Reuther, Sexism and God-Talk: Toward a Feminist Theology (1983) and M. Warner, Alone of All Her Sex: The Myth and the Gult of the Virgin Mary (1985).

27. Radford Reuther, supra n.26, at 98. The author also examines some "egalitarian theologies" which have rejected the mainstream patriarchial ideas about the relation of men and women to God; see id. at 99-109. Some of these alternative explanations inform the present feminist critique of theology; see, for example, Radford Reuther, The Feminist Critique in Religious Studies in Langland and Gove, eds., supra n.1, at 52.

28. See S. Okin, Women in Western Political Thought (1979).

29. Id. at 9.

30. Id. at 279. See also, S. Ruth, Methodocracy, Misogyny and Bad Faith: The Response of Philosophy in Spender, supra n.4, at 43. 
tions they asked rather than to those they did not ask, and confirmation of differences rather than similarities between women and men. Thus,

The distinctions between female and male were weighed and measured, explained and interpreted: scientists took over from philosophers the task of assigning to women their proper place in the social order. ${ }^{31}$

The ideas described above were those current in the mainstream of intellectual life at the turn of the century. There were, of course, other ideas also current at that time: ideas of religious equality among the Shakers, and among liberals such as the Grimke sisters; ${ }^{32}$ ideas about gender equality, however flawed, in the work of philosophers like Mill $;^{33}$ and scientific ideas about the influence of environment on the respective traits of men and women. ${ }^{34}$ Yet such ideas were less well embraced by $\mathrm{Mr}$. Justice Barker.

It is significant in Mabel French's case, however, that the court uncritically accepted ideas from the mainstreams of religion, philosophy, and science, as if they were factual rather than conceptual. Moreover, in accepting those ideas and making them an essential part of his decision, Mr. Justice Barker provided an explicit and very significant reinforcement of the idea of gender-based difference. In this way, the particular decision to deny Mabel French's claim to practice law had an impact which was felt well beyond the instant case. Thereafter, in the law, as well as in other intellectual traditions, there was established a recognized and "legitimate" difference between women and men. ${ }^{35}$

Two other points must also be mentioned. It is significant to an assessment of legal method that the ideas about the role of women, first expressed in the Bradwell case in 1873, were adopted unquestioningly over thirty years later in French's case in 1905. That the court apparently did not question the appropriateness of applying a precedent from an earlier generation, and from a foreign jurisdiction, seems remarkable. The possibility of distinguishing the earlier decision is clear and the court's acceptance of the Bradwell decision as both relevant and apparently binding is initially perplexing. ${ }^{36}$

The Bradwell decision also relied in part on the inability of married

31. See, Women's Nature and Scientific Objectivity in Lowe and Hubbard, eds., Woman's Nature: Rationalizations of Inequality (1983) 9, at 12. See also, Hubbard, The Emperor Doesn't Wear Any Clothes: The Impact of Feminism on Biology in Spender, supra n.4, at 213.

32. Radford Reuther, supra n.26.

33. Okin, supra n.28. 300.

34. For examples, see M. Stein Wortman, Women in American Law (1985), at 296-

35. This point is important in relation to arguments about the legitimating force of the law. See, for example, O'Donovan, supra n.4, at chapter 1 .

36. It is also noteworthy that the court in French failed to consider the admission of Glara Brett Martin in Ontario, a precedent (albeit one achieved by legislative action) that might have been considered more apt than Bradwell's. 
women to enter into contracts because of the common law disability that was still in existence in 1873. Mr. Justice Barker might have commented on the fact that married women's property legislation, both in Canada and in the United States, had erased most of these disabilities by 1905 . This fact would have provided an additional reason for distinguishing rather than following Bradwell. As such analysis demonstrates, the Bradwell precedent was not self-applying, and there was a choice to be made by the court in French. The more difficult problem, therefore, is to explain the reasons for the judicial choice.

More fundamentally, the ideas accepted in Bradwell and restated in French were quite inconsistent, and probably known to be so by the judges, with the reality of "women's work" outside the home at the turn of the century. In Canada, as well as in Great Britain:

Very few of the women whom the judges knew, whether they were litigants, or cleaners of the courtroom, or servants in the home, actually corresponded in any way to the judicial representation. At the time when the judges were speaking, more than a million unmarried women alone were employed in industry, while a further three quarters of a million were in domestic service. . . . For the great majority of Victorian women, as for the great majority of Victorian men, life was characterized by drudgery and poverty rather than by refinement and decorum. ${ }^{37}$

Despite this reality, Mr. Justice Barker reiterated without criticism or qualification the authoritative statement from Bradwell:

The paramount destiny and mission of women are to fulfill the noble and benign offices of wife and mother. This is the law of the Greator. And the rules of civil society must be adapted to the general constitution of things, ... ${ }^{38}$

The conflict between the judicial description of all women, and the known conditions in which at least some of them lived at that time, suggests a further element of legal method: its abstraction from the "real" lives of women. Indeed, what seems evident is a willingness to use the ideas of (male) theologians, philosophers, and scientists as the basis of "reality" in preference to the facts of life in the lives of actual women.

The judicial approach evident in French changed significantly, however, by the time of the Persons case. There is little mention in that case of gender-based difference in the analysis of either the Supreme Court of Canada or the Privy Council. In the Supreme Court of Canada, indeed, the only hints of any unusual aspect of the case occurred when Mr. Justice Mignault referred to the petitioners' claim as a "grave constitutional

37. A. Sachs and J. Hoff Wilson, Sexism and the Law (1978), at 54. See also, S. Mann Trofimenkoff and A. Prentice, The Neglected Majority (1977).

38. Supra n.12, at 366. 
change,"38 and Mr. Justice Anglin restated the "apologia" from Chorlton v. Lings (1868) ${ }^{40}$ that:

... in this country in modern times, chiefly out of respect to women, and a sense of decorum, and not from their want of intellect, or their being for any other such reason unfit to take part in the government of the country, they have been excused from taking any share in this department of public affairs. ${ }^{11}$

However, nothing in the judgments of the Supreme Court of Canada reflects the rhetoric and ideas expressed by Mr. Justice Barker in Mabel French's case. Indeed, by contrast, Lord Sankey commenced his opinion in the Privy Council by stating:

The exclusion of women from all public offices is a relic of days more barbarous than ours, but it must be remembered that the necessity of the times often forced on man customs which in later years were not necessary. ${ }^{42}$

His words suggested a clear signal that, although the treatment of women in the past may have been understandable in the context of those times, the world had changed.

In the Persons case, the quote above is the only reference to the difference between men and women. The contrast between the reliance on gender-based difference as incontrovertible fact in French at the turn of the century, and the virtual absence of such ideas in the Persons case in the late 1920 's, is highly significant. It offers an explanation for the differing outcomes in the two cases: when difference was emphasized in French, women were excluded from membership in the legal profession; when it was discounted as in the Persons case, women were included with men in the opportunities to participate in public life.

This approach to the cases, based as it is on the methodology actually observed in the two judicial decisions, suggests that the dictates of legal methods were not strictly followed by the judges in their decision-making process. In addition to this approach, however, it is necessary to assess the legal method actually described by the judges in the cases. The contrast between what they said they were doing, and what they actually did, also offers some important insights into legal method. To this contrast we now turn.

\section{The Principles of Legal Method}

The stated reasons in these cases were consistent with well-established principles of legal method. The principles can be analyzed in terms of three aspects: (1) the characterization of the issues; (2) the choice of

39. S.G.C., supra n.16, at 303.

40. L.R. 4 C.P. 374 (1868).

41. S.C.C., supra n.16, at 283.

42. J.C.P.C., supra n.16, at 128. 
legal precedent to decide the validity of the women's claims; and (3) the process of statutory interpretation, especially in determining the effect of statutes to alter common law principles. Both the principles themselves and their application to these specific claims are important for an understanding of the potential impact of feminism on legal method.

\section{Characterizing the Issue}

In both the French case and the Persons case, the judges consistently characterized the legal issues as narrowly as possible, eschewing their "political" or "social" significance, and explaining that the court was interested only in the law. ${ }^{48}$ For example, in the Persons case in the Canadian Supreme Court, Chief Justice Anglin stated pointedly:

In considering this matter we are, of course, in no wise concerned with the desirability or the undesirability of the presence of women in the Senate, nor with any political aspect of the question submitted. Our whole duty is to construe, to the best of our ability, the relevant provisions of the B.N.A. Act, 1867, and upon that construction to base our answer. ${ }^{\text {t4 }}$

Even the Privy Council, which came to a distinctly different conclusion, framed the scope of its judicial inquiry as narrowly as possible:

Their Lordships are concerned with the interpretation of an Imperial Act, . . . Nor are their Lordships deciding any question as to the rights of women but only a question as to their eligibility for a particular position. No one either male or female has a right to be summoned to the Senate. The real point at issue is whether the Governor-General has a right to summon women to the Senate. ${ }^{45}$

Glearly evident in these judicial statements is a felt need to distance the court from the "political" or moral issue, and a desire to be guided only by neutral principles of interpretation in relation to abstract legal concepts. The justices' confidence in the principles of legal method as a means of deciding the issue, even confined so narrowly, is also evident. While their comments suggest an awareness of broader issues, there is an assertion of the court's limitation in resolving the dispute.

Just as clearly, the women claimants never intended to bring to the court a "neutral" legal issue for determination; they petitioned the court to achieve their objectives, and their goals were evidently "political"

43. The same approach occurred in relation to Clara Brett Martin's application to the Law Society in Ontario. The lawyer chairing the Committee responsible for looking into the matter reported to the Benchers that the issue was whether the Law Society was "permitted to allow a woman to be entered as a Student of Laws" rather than whether it was "desirable" that they be so admitted. See, Backhouse, supra n.8, at 8; citing Woman as Students-at-Law, 2 Western Law Times 118-9 (1891).

44. S.C.C., supra n.16, at 281-2.

45. J.C.P.C., supra n.16, at 137. 
ones. ${ }^{48}$ Yet the court expressed views of judicial process as neutral interpretation. More significantly, the court's power to define the "real issues" carried with it an absence of responsibility on the part of the male judges for any negative outcome. It was the law, rather than the male person interpreting it, which was responsible. The result of the characterization process, therefore, is to reinforce the law's detachment and neutrality. rather than its involvement and responsibility; and to extend these characteristics beyond law itself to judges and lawyers involved as well.

Yet, it is difficult to accommodate this characterization of detachment and neutrality with the opinions expressed, especially in French, about the roles of women. The ideas about gender-based differences expressed forcefully by Mr. Justice Barker in that case appear very close to an expression about the "desirability" of women lawyers and are not merely dispassionate and neutral in their application of legal precedents. Thus, at least in French, there is an inconsistency between the legal method declared by the judges to be appropriate, and the legal method actually adopted in their decision-making. In this context, the idea of detachment and neutrality both masks and legitimates their personal views about women's "proper" sphere.

\section{Using Precedents in the Common Law Tradition:}

The existence of women's common law disability was regularly cited in both these cases as the reason for denying the claimants' admittance to the legal profession and participation in public life. The judges used numerous precedents for their conclusions. For example, Chief Justice Anglin cited as a "fact or circumstance of importance":

... that by the common law of England (as also, speaking generally, by the civil and the canon law...) women were under a legal incapacity to hold public office, ....47

At the end of the nineteenth century, of course, women (especially married women) suffered disabilities at common law in a number of respects: married women were denied the right to hold interests in property until the married women's property statutes ${ }^{48}$, and all women were denied the right to vote until the 20 th century. ${ }^{49}$ As well, however, courts regularly asserted that, because of women's common law disabilities, there were no

46. See G. Mander, Emily Murphy: Rebel Grusader (1985).

47. S.C.C., supra n.16, at 283.

48. There are several monographs analyzing the process of matrimonial property reform on both sides of the Atlantic in the latter half of the nineteenth century; for example, see L. Holcombe, Wives and Property: Reform of the Married Women's Property Law in Nineteenth-Century England, (1983); N. Basch, In the Eyes of the Law: Women, Marriage and Property in Nineteenth-Gentury New York (1982); and E. Griffith, In Her Own Right: The Life of Elizabeth Cady Stanton (1984).

49. The right to vote was generally extended to women in both England and Canada during or just after World War I. 
precedents for admitting women to the legal profession or to full participation in public life. ${ }^{50}$ In French, for example, Mr. Justice Barker stated emphatically:

It is, of course, useless to look to Westminster Hall to find a precedent in such a case, because it seems clearly established that there is no instance to be found in the records of any court in England of any such application being made. 51

It has been suggested that the absence of such a common law precedent can be traced to Lord Coke who (apparently without the benefit of precedent) "had stated that women could not be attorneys" three hundred years previously. ${ }^{\mathrm{g}}$ The absence of precedents declaring women eligible to take part in public life and to enter the legal profession created a significant handicap for counsel presenting arguments in favor of the women's claims.

From a broader perspective, moreover, this difficulty epitomizes the negative effects of the doctrine of precedent on newly-emerging claims to legal rights. If a precedent is required in order to uphold a claim, only existing claims will receive legal recognition. The doctrine of precedent thus becomes a powerful tool for maintaining the status quo and for rationalizing the denial of new claims. Seen in this light, the law itself is an essential means of protecting the status quo, notwithstanding the challenge of feminist ideas.

However, if this conclusion is correct, how can the Privy Council's decision be understood? It was a decision which did not utilize the doctrine of precedent as had its predecessors. After canvassing the precedents, Lord Sankey stated:

The fact that no woman had served or has claimed to serve such an office is not of great weight when it is remembered that custom would have prevented the claim being made or the point being contested. Customs are apt to develop into traditions which are stronger than law and remain unchallenged long after the reason for them has disappeared. The appeal of history therefore in this particular matter is not conclusive. $^{.5}$

Obviously, the Privy Council in the Persons case was less concerned with the absence of precedent in their decision-making than the judges in French. Is the Privy Council's approach simply an early example of a court of highest jurisdiction deciding not to be bound by precedent in certain cases, or is there some other explanation?

One suggestion is that the decision of the Privy Council in 1929 sim-

50. In Sachs and Wilson, supra n.37, there is a full description of the cases in England and the United States, and some information, about the cases in Canada and South Africa: see id. at 1-132 and 168-199.

51. Supra n.12, at 364.

52. Sachs and Wilson, supra n.37, at 32.

53. J.C.P.C., supra n.16, at 134. 
ply reflected the spirit of the times in relation to the role of women. Much had indeed changed since Clara Brett Martin and Mabel French had sought admission to the legal profession at the turn of the century. As was noted earlier, there had been legislation enabling married women to enter into contracts and to hold interests in property even before the end of the nineteenth century. In the early part of the twentieth century, moreover, women had participated actively in World War I; and they had attained suffrage in many jurisdictions after the war $^{54}$ and the benefit of the Sex Disqualification (Removal) Act in England in 1919..5 It may, therefore, be quite accurate to conclude that:

There is nothing in legal logic itself which explains the turnaround of the judges in [the Privy Council case] . . . . In the absence of any other satisfactory explanation, the conclusion becomes inescapable that what had changed was not ... the modes of reasoning appropriate to lawyers, but the conception of women and women's position in public life held by the judges. ${ }^{\text {s6 }}$

At the same time, if this explanation is accepted, it is difficult to account for the differences in perspective of the judges of the Supreme Court of Canada in 1928 from those in the Privy Council in 1929. It is true that Lord Sankey sat in the English Cabinet alongside Margaret Bondfield, ${ }^{52}$ the first woman to hold Cabinet office in Britain; and it is, therefore, possible that he had become accustomed to the idea of women holding public office as a result of this "precedent." course, depends on the assumption that no similar role models existed in Canada. Yet such a conclusion denies the importance of the roles of the five women challengers in the Persons case: Henrietta Muir Edwards was the Alberta Vice-President of the National Council of Women for Canada, Nellie McClung and Louise McKinney had been members of the Legislative Assembly in Alberta, Irene Parlby was a member of the same Legislative Assembly and of its Executive Council, and Emily Murphy was the first woman police magistrate in Alberta. ${ }^{.8}$ It is therefore difficult, if not impossible, not to accept these Canadian women as "precedents" equal to Margaret Bondfield. What, then, is the explanation for these differing perspectives of the justices and the different outcomes that resulted in the two courts?

In terms of the legal method described by the judges, of course, there is no answer to this question. Neither the judgments in the Supreme Court of Canada nor Lord Sankey's opinion in the Privy Council ex-

54. Sachs and Wilson, supra n.37.

55. Sex Disqualification (Removal) Act, 1919, 9-10 Geo. V, ch. 71.

56. Sachs and Wilson, supra n.37, at 41.

57. Id.

58. This conclusion is suggested by Sachs and Wilson, $i d$. at 42 .

59. J.C.P.C., supra n.16, at 126; none of the members of the "Alberta Five" could have been dismissed as less than very talented and exceptional women. For details about them, see C. Mander, supra n.46, at 110-114. 
pressly consider at all the realities of women's experiences of the time, and they specifically do not consider the realities of experience for the actual women claimants in the Persons case. Thus, even if the judges' perspectives on women's place were different in the two courts, ${ }^{60}$ there is virtually nothing in their judgments expressly reflecting them. For this reason, it is impossible to demonstrate that Lord Sankey's differing perspective was the reason for the different outcome in the Privy Council. At the same time, however, it is hard to find any other convincing explanation.

What does seem clear is the existence of judicial choice in the application of precedents. In the process of choosing earlier cases and deciding that they are binding precedents, the judges were making choices about the aspects of the cases which were "relevant" and "similar", choices which were not neutral but normative. In suggesting that the earlier decisions (relied on by the Supreme Court of Canada as binding precedents) were not determinative, Lord Sankey was declaring that the precedents should not be regarded as exactly the same as the situation before the court in the Persons case. In this way, Lord Sankey's decision demonstrates the availability of choice in the selection of facts, in the categorization of principles and in the determination of relevance. At the same time, his opinion completely obscures the process and standards which guided the choice he actually made. To the myth of "neutrality", therefore, Lord Sankey adds the "mystery" of choice.

\section{Interpreting Statutes and Parliament's Intent}

The interpretation of the law relating to women's claims was complicated by the need for judges to construe statutes as well as take account of the common law principles. In some earlier cases, for example, women had challenged their exclusion from statutory rights when statutory language referred only to "men". Such claims were based on earlier legislation $^{61}$ in England which provided that "words importing the masculine gender should be deemed and taken to include females, unless the contrary was clearly expressed." In Chorlton $v$. Lings ${ }^{62}$, a case involving the right to register to vote under legislation providing a voting right to any "man", the court dismissed the women's claim on the basis that it could not have been the wish of Parliament to make so drastic a change. If Parliament wished to enable women to vote, it would not have used the word "man"ss to establish the voting qualifications in the statute.

60. See, for example, Lord Sankey's comment, supra n.42, about the "times more barbarous than our own."

61. Lord Broughham's Act, 1850, ch. 21, $\$ 4$ stated:

That in all Acts words importing the masculine gender shall be deemed and taken to include females... unless the contrary as to gender . . . is expressly provided.

62. Supra n.40.

63. According to Sachs and Wilson, supra n.37, at 23, John Stuart Mill had made some efforts, at the time of the enactment of the Second Reform Bill in 1867 (which 
Even in the statutes which used gender-neutral language, however, there were problems of statutory interpretation in cases which challenged male exclusivity. The legislation reviewed in the Persons case, as well as in the cases of both Glara Brett Martin and Mabel French, used the word "person" in describing the qualifications for appointment to the Senate and admission to legal practice, respectively. In the Persons case in the Supreme Court of Canada, Chief Justice Anglin expressed his surprise that such a monumental change in the position of women could be conferred by Parliament's use of such an insignificant means:

Has the Imperial Parliament . . . given to women the capacity to exercise the public functions of a Senator? Has it made clear its intent to effect . . the striking constitutional departure from the common law for which the petitioners contend, which would have rendered women eligible for appointment to the Senate at a time when they were neither qualified to sit in the House of Commons nor to vote for candidates for membership in that House? . . . Such an extraordinary privilege is not conferred furtively. . . . ${ }^{\text {st }}$

Not surprisingly he then concluded that the claim of these five women must be dismissed because there was no evident express intent on the part of Parliament to effect the change advocated by them; the use of the word "person" was not, by itself, sufficient.

A similar result occurred in Mabel French's challenge in the New Brunswick court. The legislation governing the admission of lawyers to legal practice used the word "person." Indeed, the legislation in New Brunswick had used gender-neutral language for many years. Unfortunately, this latter fact reinforced the judges' conclusion that the statute could not have been intended to include women, because they had never been lawyers. ${ }^{65} \mathrm{Mr}$. Justice Barker had no doubt at all as to the appropriate resolution of this problem of statutory interpretation:

It is very evident, $I$ think, that neither this court in any of the rules which it has made or sanctioned, nor the Barristers' Society in the rules which it has made, nor the legislature in enacting [this statute], had any thought or intention of making the radical change now suggested, and that by every rule of construction applicable to such a case this court is bound to hold that no such change has been made. ${ }^{68}$

Thus, the Ganadian judges uniformly interpreted the word "person" in a way that seemed most consistent with their time and experiences. For them, it was radical indeed to think of a woman in public office or in the

extended the Parliamentary suffrage), to change the word "man" in the statute to "person". His efforts were unsuccessful. But one of his opponents had suggested that the legislation of 1850 would nonetheless enfranchise women. The negative outcome of Chorlton v. Longs, supra n.40, of course, demonstrated that the 1850 legislation would also be interpreted in accordance with prevailing cultural values.

64. S.C.C., supra n.16, at 285.

65. Supra n.12, at 370-1.

66. $I d$, at 371 . 
legal profession, and their interpretation of the statutory language reflected their own understanding of what Parliament might have "intended", had Parliament considered the matter explicitly. Presumably, the judges also felt confident that members of Parliament, (male) people much like the judges themselves, would have agreed with their interpretation. This conclusion, which reinforces the notion of judges as "imprisoned" in their own social class, gender, and status, presents no surprise.

Once again, however, the opinion of the Privy Council is different. After reviewing at some length the legislative provisions of the B.N.A. Act, Lord Sankey stated:

The word 'person' . . . may include members of both sexes, and to those who ask why the word should include females, the obvious answer is why should it not? In these circumstances the burden is upon those who deny that the word includes women to make out their case. ${ }^{67}$

No precedent was cited to support this presumption in favor of the most extensive meaning of the statutory language, even though it expressly contradicted the principles of statutory interpretation adopted in the decision of the Supreme Court of Canada. ${ }^{68}$

In the end, just as the Privy Council decision was puzzling in relation to the effect of legal precedents about women's common law disabilities, it is also difficult to reconcile Lord Sankey's conclusions about the interpretation of the statute to the principles and precedents accepted in the Supreme Court of Ganada. Clearly, the Privy Council departed from the Supreme Court's approach to legal method in reaching its conclusion to admit the women's claims. It is less clear how we should identify Lord Sankey's reasons for doing so.

In this context, what conclusion is appropriate in discerning feminism's potential for perspective transforming in the context of legal method?

\section{Feminism and Legal Method}

The analyses of these cases illustrates quite well the structure of inquiry identified as legal method. First of all, legal method defines its own boundaries. Questions which are inside the defined boundaries can be addressed, but those outside the boundaries are not "legal" issues, regardless of their importance to "politics" or "morals", etc. Thus, the question of women becoming lawyers or senators was simply a matter of interpreting the law; it did not require any consideration of utility or benefit to the women themselves or to society in general. The purpose and the result of the boundary-defining exercise are to confer "neutrality" on the law and on its decision-makers. In so doing, the process also relieves both the law and its decision-makers of accountability for unjust or just deci-

67. J.G.P.C., supra n.16, at 138 .

68. J.C.P.C., supra n.16. 
sions-("our whole duty is [only] to construe ... the provisions of the [constitution]"). ${ }^{89}$

More sinister than this boundary-defining exercise is the potential for judicial attitudes to be expressed, and to be used in decision-making (either explicitly or implicitly), when there is no "objective" evidence to support them. Because of the myth of neutrality which surrounds the process, such attitudes may acquire legitimacy in a way that strengthens and reinforces ideas in "politics" and "morals" which were supposedly outside the law's boundary. After the decision in French, for example, women were different as a matter of law, and not just in the minds of people like Mr. Justice Barker. Thus, the power to name the boundaries of the inquiry (and to change them, if necessary) makes legal method especially impervious to challenges from "the outside."70

Second, legal method defines "relevance" and accordingly excludes some ideas while admitting others. Some facts, such as inherent genderbased traits, were regarded as relevant in French, for example, while in both French and the Persons case the actual conditions in which women lived their lives were not relevant at all. Glearly relevant in both cases, however, were earlier decisions about similar circumstances from which the judges could abstract principles of general application. That all of the earlier cases had been decided by men, who were interpreting legislation drafted when women had no voting rights, was completely irrelevant to the decision-making in the cases analyzed even though the cases represented direct and significant challenges to the continuation of gender-exclusive roles (and the circumstances of the historical context seem quite significant to us). The irony of solemn judicial reliance on precedents that excluded women, in the context of significant efforts by women to change the course of history, underlines the significant role of legal method in preserving the status quo.

Finally, the case analyses demonstrate the opportunity for choice in legal method: choice as to which precedents are relevant and which approach to statutory interpretation is preferred; and choice as to whether the ideas of the mainstream or those of the margins are appropriate. The existence of choice in legal method offered some possibility of positive outcomes in the women's rights cases, when at the same time legal method's definition of boundaries and concept of relevance ensured that positive outcomes would seldom occur. Lord Sankey's opinion in the Privy Council is an example of choice in legal method which is as remarkable for its common sense as it is for its distinctiveness in legal method. Because Lord Sankey obscured the reasons for his choice, however, he also preserved the power and mystery of legal method even as he endowed women with the right to be summoned to the Senate. Thus, the opportunity for choice of

69. S.G.G. supra n.44.

70. It is interesting that Cynthia Fuchs Epstein, in her study of women lawyers in the United States, referred to them as "outsiders." See C. Epstein, Women in Law 385 (1981). 
outcome, positive as it appears, will not automatically lead to legal results which successfully challenge "vested interests" or the "status quo", especially in relation to the law itself.?

That legal method is structured in such a way that it is impervious to a feminist perspective is a sobering conclusion. Within the women's movement, it has important consequences for the design of strategies to achieve legal equality. It suggests, for example, the general futility of court action for achieving significant change in women's rights, even though litigation of women's claims may be useful to monitor interpretation by courts or to focus attention on legal problems. For a feminist who is also a lawyer, however, the effort of "double-think" may be both taxing and ultimately frustrating. The needs of clients require her to become highly proficient at legal method while her feminist commitment drives her to challenge the validity of its underlying rationale.

This dilemma also exists for feminist scholars. Feminist legal scholars are expected to think and write using the approaches of legal method: defining the issues, analyzing relevant precedents, and recommending conclusions according to defined and accepted standards of legal method. A feminist scholar who chooses instead to ask different questions or to conceptualize the problem in different ways risks a reputation for incompetence in her legal method and may put her feminist accomplishments on the line. Too often, it seems almost impossible to be both a good lawyer and a good feminist scholar. ${ }^{72}$

The dilemma is similarly acute for feminist law teachers and students. With the advent of large numbers of women law students and increasing numbers of women on law faculties, ${ }^{73}$ many people have concluded that there is now a feminist perspective in the law school. Such a conclusion ignores the power of legal method to resist structural change. For example, discussions about whether feminist law teachers should create separate courses with feminist approaches and content, or whether such approaches and content should be used in "malestream" courses, or whether both should be done at once, etc., clearly reinforce the "reality" of the existing categories of legal knowledge, and the idea of the feminist perspective as "Other"." While the separate course approach marginalizes the feminist perspective, the process of "tacking on" feminist approaches to "malestream" courses only serves to emphasize what is really important in contrast to what has been "tacked on". Even efforts to give equal time to the feminist perspective and to reveal the essential maleness

71. For an interesting analysis of the process of interpreting constitutional texts, see Levinson, Law as Literature, 60 Texas L.R. 373 (1982).

72. See Lahey, . . . until women themselves have told all they have to tell . . ., 23 Osgoode Hall L.J. 519 (1985).

73. See Mossman, Portia's Progess: Women as Lawyers-Reflections on Past and Future, Law Society of Upper Canada, Conference Paper, May 1986.

74. See Mossman, "Otherness" and the Law Schools: A Comment on Teaching Gender Equality, 1 Canadian Journal of Women and the Law 213 (1985). 
of the "neutral" approach may underline that what is male is what really has significance. On this basis, adding women's experience to the law school curriculum cannot transform our perspective of law unless it also transforms legal method.

This focus on methodology is significant. In the ethical dilemmas posed to Amy and Jake in the research of Garol Gilligan, ${ }^{75}$ the nature of their responses was quite distinctive. Essentially, Jake accepted the conceptual framework which dominates our culture- hierarchies and abstractions-which encourage decisive and dichotomous thinking. Amy's response was more tentative, with the conceptualization blurred by an unwillingness to abstract from the needs of the particular people involved. According to Carrie Menkel-Meadow, ${ }^{76}$ Amy is the typical first year law student who resists the dictates of legal method: she wants more facts, she refuses to exclude some ideas as "irrelevant" to the decision-making process, and she will not accept the need to abstract from the particular circumstances and make an either/or decision. ${ }^{77}$

If Menkel-Meadow is correct, what is the role of a law teacher, faced with a class of first year students like Amy? Typically, it is to assert rigorously the process of legal method epitomized by Jake's response. Moreover, the success of law teachers in turning students like Amy into students like Jake is evidenced by the large numbers of women lawyers and law teachers who are able to reason like Jake and who believe that their success in doing so represents another step in achieving equal rights for women. ${ }^{78}$ Yet, the reality might be that such women have been transformed by legal method to envision legal problems from a male perspective. In this respect, there appears to be a power in legal method to "transform" the perspective of women in law. Is there, however, any potential for "perspective transforming" of legal method by feminism?

In my experience, the story of Amy and Jake and their differing responses to Heinz' dilemma never fails to provoke a group of people, male or female, into animated discussion. For many women, and also for some men, the picture of Amy produces a shock of self-recognition. Her unwillingness to accept the rules makes her instantly recognizable by anyone who is not content with the world as it is. Both Gilligan and MenkelMeadow acknowledge that some of Amy's ideas may be voiced other than by women. The fact that Amy's different voice has strong connections

75. G. Gilligan, In a Different Voice (1982). Amy and Jake (both eleven years old) were asked to decide whether a man called Heinz should steal a drug in order to save the life of his wife who was dying of cancer. Jake reported that, because life is more important than property, Heinz should do so. Amy's response was more complex, attempting to "solve" the problem without a necessary dichotomy. See Gilligan, at 25-35.

76. Menkel-Meadow, Portia in a Different Voice: Speculating on a Women's Lawyering Process, 1 Berkeley Women's Law Journal 39 (1985).

77. Id. at 46.

78. Mossman, supra n.73. 
with women's experiences, however, reinforces the notion of their dissatisfaction, as a group, with the world as it presently is.

At the same time, the difference in Amy's response to the problem presented does not necessarily lead to a conclusion that women and men are inherently different, and should not be regarded as proof of assertions of inherent differences, like those evident in the French case. Indeed, the difference in Amy's response might itself derive from women's relative powerlessness (or invisibility) within societal structures, including law, as they have existed to date. This view has been most compellingly expressed by Catharine MacKinnon:

I do not think that the way women reason morally is 'morality in a different voice'. I think it is morality in a higher register. Women value care because men have valued us according to the care we give them, and we could probably use some. Women think in relational terms because our existence is defined in relation to men. Similarly, I think that when you are powerless, you don't just speak differently. A lot, you don't speak. Your speech is not just a (sic) differently articulated, it is silenced. Eliminated, gone. You aren't just deprived of a language within which to articulate your distinctiveness, you are deprived of a life out of which articulation might come. ${ }^{7 \theta}$

Such a critique exposes the structural barriers within the law that prevent Amy's voice from being heard. It also suggests the importance of law in reinforcing patriarchal norms, and implicitly denies the possibility that feminism can transform the perspective of legal method, at least in the absence of changes in women's real political power.

Taking this conclusion seriously, as I think we must, leads to some significant conclusions for women who are feminists and who are lawyers, law teachers or law students. It is simply not enough just to introduce women's experience into the curriculum or to examine the feminist approach to legal issues, although both of these activities are important. There is no solution for the feminist who is a law teacher except to confront the reality that gender and power are inextricably linked in the legal method we use in our work, our discourse, and our study, especially because there is so much resistance in legal method itself to ideas that challenge the status quo. Honestly confronting the barriers of our conceptual framework may at least permit us to begin to ask more searching and important questions. ${ }^{80}$

Thus, if feminism has a power to transform the perspective of legal method, it must be because it permits feminists "a new way of seeing"

79. MacKinnon, Difference and Dominance: On Sex Discrimination, unpublished manuscript, paper delivered to the Harvard Law School, Spring 1984. See also, Marcus and Spiegelman, moderators, Feminist Discourse, Moral Values, and the Law-A Conversation, 34 Buffalo L.R. 11 (1985).

'80. Christine Boyle has begun to ask such questions, I think, in Teaching Law as if Women Really Mattered, unpublished paper, Canadian Association of Law Teachers, May 1986. 
both the reality of present lives and of imagining better ones. As Adreinne Rich defines the challenge, feminists need imagination "not merely for changing institutions but for human relationships; not merely for equal rights but for a new kind of being."BI That, in the end, is the task that awaits the work and the imagination of feminist lawyers.

81. A. Rich, Toward a Woman-Centered University, On Lies, Secrets and Silences (1979) 125 , at 155. 